\title{
Land cover and land use change analysis: Its impacts on rangeland ecosystems in Kakooge County, Nakasongola district, Uganda.
}

James Mbaziira ${ }^{1}$,*

(C) Uganda Martyrs University

\begin{abstract}
The paper presents and reviews the land cover and land use changes within a rangeland ecosystem and their impacts for a period of 18 years (1987-2005) in Nakasongola district, specifically, Kakooge County. The study used ArcGIS 10.2 data, field observations and community perceptions. Results showed a typical change in built areas, bush lands and subsistence farmlands expanded by $822.2 \%$ in 1987 and $61.7 \%$ in 2015 , while commercial farmland, forest plantations, wetlands and woodland declined by $1.5 \%, 67.5 \%, 37.6 \%$ and $6.5 \%$ respectively. The changes in land cover and land uses originated from poverty, charcoal production, occurrence of drought, and introduction of pine plantations by $41 \%, 37 \%, 55 \%$ and $50 \%$. Similarly, this resulted into frequent droughts, reduced soil productivity, food insecurity, and wood fuel crisis by $98 \%, 67 \%, 33 \%$, and $36 \%$, respectively. There was also general decline of land holding per household from 1.6ha to 1.5ha. Thus, such cumulative effects contribute to rangeland degradation calling for appropriate management measures like strengthening environmental monitoring and ecosystem conservation strategies, extending poverty alleviation programmes and integrating of tree planting into the farming system in a more collaborative way to halt the outpacing impacts.
\end{abstract}

Keywords $\cdot$ Rangelands $\cdot$ Landsat $\cdot$ Ecosystem $\cdot$ Land cover $\cdot$ Land use change.

\section{Introduction}

Rangelands relate to the world's most sensitive ecosystems adversely affected by inappropriate land uses (Zziwa et al., 2011). Globally, rangelands are under intense pressure from natural and human induced factors (Mbaziira, 2016; Tsegaye et al., 2012). Since 1950, about 10.7 million $\mathrm{km}^{2}$ of the world lands occupied by grassland and woodland have been changed to farmlands (Kimiti et al., 2016). In Uganda, rangeland ecosystem decline is most pronounced in the dry corridor which stretches diagonally from the northeast through the central to the south western parts of the country covering a total land area of 84000km sq. ( 40\%), (NEMA, 2008; UNDP, 2009).

\footnotetext{
${ }^{1}$ Uganda Martyrs University, *jmbaziira@umu.ac.ug
} 
The gradual increase in land cover and land use changes in rangelands of Kakooge, Nakasongola district emanates from a complex mixture of drivers, which have turned out to be a substantial problem for rangeland management. The state of the changes largely differ depending on the anthropogenic influences like increased demand for fuel wood from woodlands as the primary source of energy, and population pressure (Mbaziira, 2016; Muleneh, 2003; Lambin et al., 2001). As such, the sustainability of rangelands services in Kakooge, is at stake (Zziwa et al., 2012,) calling for continuous monitoring as a way of understanding the dynamics and utilisation of the natural resources within the region (Mwavu and Witkowski., 2008). Such information is also very crucial in enhancing the formulation of informed policies to support sustainable rangeland management and rehabilitation practices for increased natural resource protection, resilience of rangelands to changing climates and pastoral livelihoods (Zziwa et al., 2012).

There is a limited linkage between land cover and land use changes with socioeconomic surveys (Beza, 2011; Amanuel and Mulugeta, 2014). For instance, according to Kisamba-Mugerwa (2001) mapping spatial changes using remote sensing can only give quantitative descriptions than explaining the relationship of patterns of change and the driving forces. Therefore, understanding land cover and land use change implications on rangelands ecosystems is crucial for designing effective land use plans (Mbaziira, 2016). Therefore, it is essential to identify and assess the patterns and magnitudes of change and disaggregation of their causes using geospatial techniques, given "situations of rapid and often unrecorded land use change, observations of the earth from space provide objective information of human utilisation of the landscape" (Sreenivasulu et al., 2014: 124). This facilitates the synoptic analyses of Earth - system functions, patterning, and change at local, regional and global scales over time; such data also provide an important link between intensive, localised ecological research and regional, national and international conservation and management of biological diversity (Sreenivasulu et al., 2014). Therefore, this study focused on analysing land cover and land use changes and their implications on rangeland ecosystems in Kakooge County from 1987 to 2005, their drivers and the related implications on the rangeland ecosystems in the area to support environmental planning.

\section{Materials and methods}

\section{Description of the study area}

The study was conducted within the rangelands of Kakooge county-Nakasongola corridor extending between $0^{0} 57^{\prime} 44.89^{\prime \prime}$ to $1^{0} 40^{\prime} 42.76^{\prime \prime}$ North and $31^{\circ} 58^{\prime} 03.77^{\prime \prime}$ and $32^{\circ} 48^{\prime} 00.29$ ' East longitude. The average altitude ranging between 3000 feet and 4550feet, with extensive uniform undulating plains panctuated by broad seasonal swamps with about $475 \mathrm{~km}^{2}$ of woodland and grassland ecosystems; and $32 \mathrm{~km}^{2}$ open 
water and wetlands and mean annual rainfall ranges between $500 \mathrm{~mm}$ to $1000 \mathrm{~mm}$ per annum with mean annual temperature $26^{\circ} \mathrm{c}$ (Nakasongola District Council (NDC), 2009).

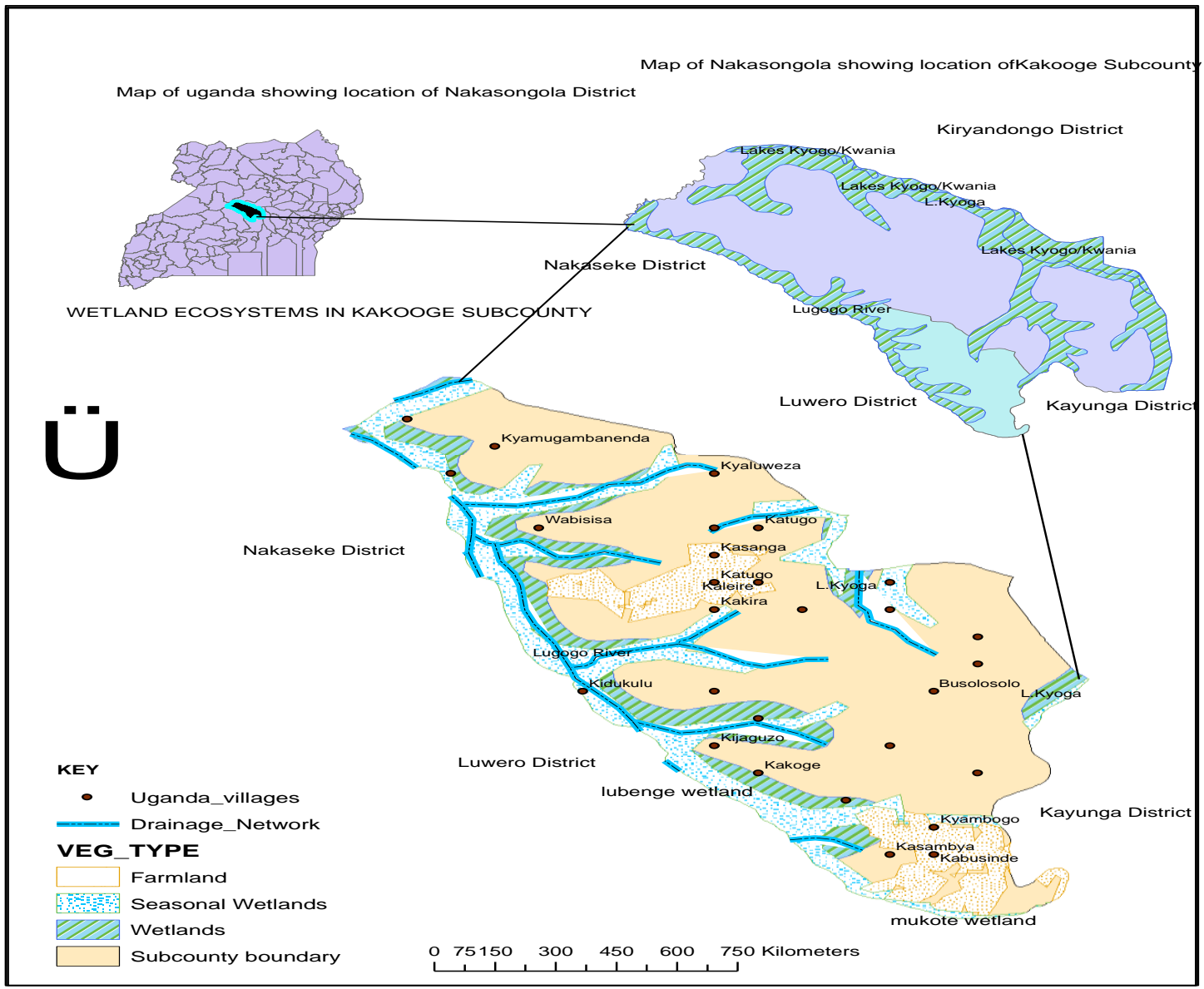

Figure 1: Location of Kakooge County within Nakasongola District Corridor. Source: Arcmap 10.1, Uganda Administrative Boundaries shape files 2014.

\section{Data collection methods for land cover and land use changes}

Satellite images of Landsat images obtained from the Global Land Cover Facility (GLCF), (2014) archive were analysed to study land cover and land use change. To obtain data for land cover and land use changes from 1987 to 2005, Thematic Mapper (5TM), and Enhanced Thematic Mapper plus (7 ETM+) of 30 metres resolution were used. These were cloud free and a topographical map (at scale 1:50,000 sheet 50/1 and 50/2 series Y732) which covers the entire area was obtained from the Department of 
Mapping and survey at Entebbe and a Google earth map was used as supplementary ancillary data for classification and accuracy assessment in Figure 1.

Each image (1987 and 2005) was geo-referenced and ortho-corrected using the basic topographic maps and a generated Arc map of the study area in ArcGis 10.1 Software. The images were imported into the arcmap info 10.1 and transformed under the raster operations using the World Geodetic System 1984 datum (WGS 84) coordinate system. Using the land cover and land use map generated for the years studied, the land cover and land use changes analysis was performed using crosstabulation, cross-classification; area losses and gains evaluation of each land cover and land use classes, and net change contribution and persistence analysis (using the land change modeller algorithm available in ArcGIS). To evaluate land cover and land use classes, about 44 Global Positioning Systems (GPS) ground truth data were collected from the field by consulting local people regarding the history of land cover and land use, their drivers and anticipated impacts on ecosystems.

The categories of land cover and land use classes for this study were adopted from the classification used by previous studies (Kafeero, 2007; Zziwa et al., 2011) in rangelands of eastern and central Uganda. For clarity, this categorisation was modified to generate eight classes as indicated in Table1.

Table 1. Land use and land cover class categorisation used in the study area

\begin{tabular}{|c|c|c|}
\hline Class & Category & Descriptions \\
\hline Class 1 & Built area & $\begin{array}{l}\text { Rural settlements that are associated with pastoral } \\
\text { production systems, permanent houses and cultivated slots. }\end{array}$ \\
\hline Class 2 & Grasslands & $\begin{array}{l}\text { Areas with permanent tall grass used for grazing but outside } \\
\text { the tree canopy }\end{array}$ \\
\hline Class 3 & Wetlands & $\begin{array}{l}\text { Primary, secondary and tertiary wetland ecosystems with } \\
\text { numerous springs clustered trees, tall grass }\end{array}$ \\
\hline Class 4 & $\begin{array}{l}\text { Subsistence farm } \\
\text { lands }\end{array}$ & $\begin{array}{l}\text { Areas used for rain fed cultivation practiced by agro- } \\
\text { pastoralists with grassland }\end{array}$ \\
\hline Class 5 & Woodlands & Dense woodlands mixed with bushes and shrubs \\
\hline Class 6 & Forest plantations & Planted pines and eucalyptus with tall grass in between \\
\hline Class 7 & Bush lands & Thickets/shrubs scattered trees but bushy \\
\hline Class 8 & $\begin{array}{l}\text { Commercial } \\
\text { farmlands }\end{array}$ & $\begin{array}{l}\text { Plantations for coffee, large scale maize gardens and } \\
\text { enclosed ranches }\end{array}$ \\
\hline
\end{tabular}

Source: Ministry of water, Lands and Environment (2003)

\section{Data analysis}

\section{Image classification and accuracy assessment}

Unsupervised classification methods were employed to classify the image and produce the land cover and land use map. Unsupervised classification was also used to provide preliminary information about the potential spectral clusters to be assigned to thematic classes. Accuracy assessments of maps were determined using error matrix and Kappa 
statistic (Congalton and Green, 2008). The validation for the classified maps of 1987 and 2005 were done using ground truth data of 44 points, which were gathered during the fieldwork. At each ground truth point, discussions were held with the local people who were familiar with land cover and land use classes to recall about their history covering the 1987 and 2005 periods.

\section{Land cover change analysis}

After Landsat images of each year were classified and labelled independently, land cover and land use change was done using a post classification comparison method, and then a comparison was made using an overlay procedure (Egeru et al,. 2014; Mbaziira, 2016). Total Area (TA), Changed Area (CA), Change Extent (CE), and Annual Rate of Change (ACR) variables were used to determine the magnitudes of change in terms of Land Use Land Cover (LULC). The variables were calculated as follows

$\mathrm{CA}=\mathrm{TA}_{\left(\mathrm{t}_{2}\right)} \mathrm{TA}_{\left(\mathrm{t}_{1}\right)}$

$\mathrm{CE}=\left(\mathrm{CA} / \mathrm{TA}_{\left(\mathrm{t}_{1}\right)}\right) * 100$

$\mathrm{CR}=\mathrm{CE} /\left(\mathrm{t}_{2-} \mathrm{t}_{1}\right)$

Where $t_{1}$ and $t_{2}$ are the beginning and ending time of the land cover studies conducted. Change detection analysis was carried out using ArcGIS 10.1 by comparing two classified land cover maps; that is, land cover for 1987 and 2005. The summaries of the areas and percentages of land cover change are presented in Table 2

\section{Socio-economic data}

Qualitative data collected from field questionnaires and household interviews was gathered, organised and summarised using tables based on themes addressed during the study. This information was used to interpret and clarify land use land cover data collected from household interviews. The Statistical Package for the Social Sciences (SPSS v.20) was used to analyse data collected from semi-structured interviews. Descriptive statistics such as means and percentages were used to present the results. 
Results and discussion

Extent of land cover and land use changes

\section{7}

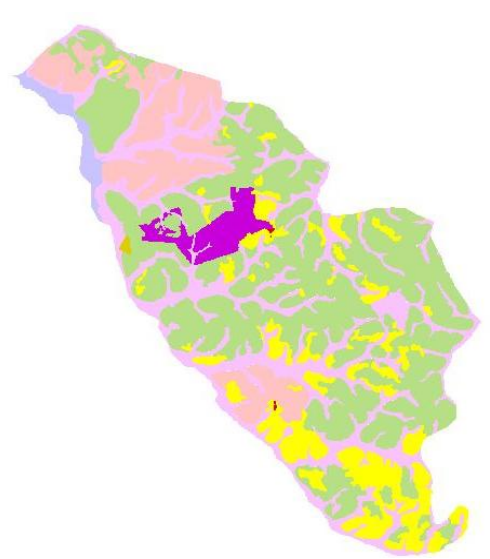

Legend

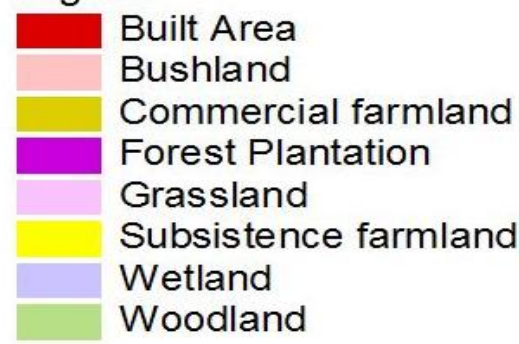

2005
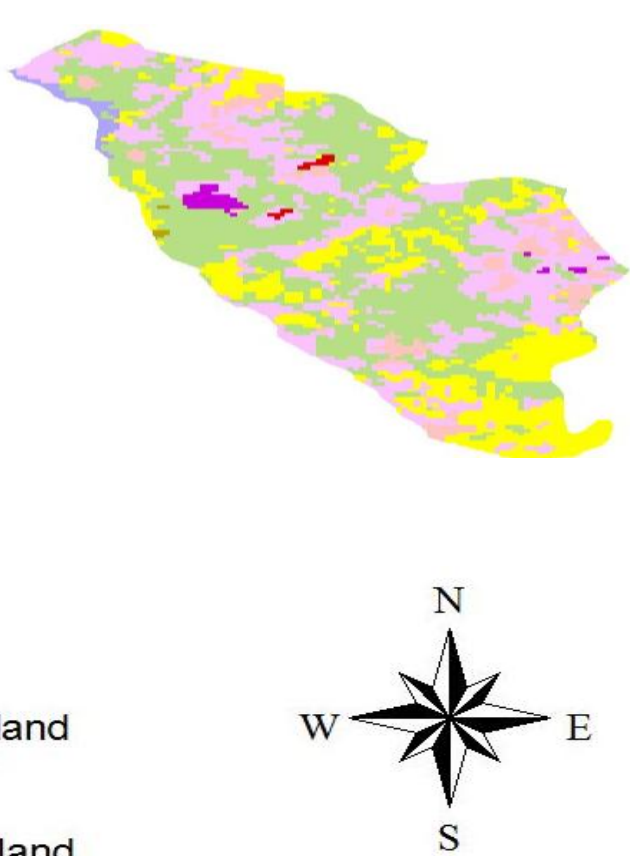

4

04

8 Kilometers

Figure 2. Land cover and land use change for Kakooge county between 1987 and 2005.

Source: ArcMap 10.1 Landsat Images for 1987 and 2005 
Table 2: The land cover and land use changes between 1987 and 2005

\begin{tabular}{lllllllll}
\hline Land use/cover type & $\mathbf{1 9 8 7}$ & & $\mathbf{2 0 0 5}$ & \multicolumn{4}{c}{ Change 1987-2005 } \\
\cline { 6 - 9 } & & & & & CA & CE & CR \\
\hline & Hectares & $\%$ & Hectares & $\%$ & Hectares & $\%$ & $\%$ \\
\hline Built areas & 18 & 0.0 & 166 & 0.3 & 148 & 822.2 & 1.8 \\
\hline Bushlands & 6,431 & 12.1 & 2,919 & 5.5 & -3512 & -54.6 & -1.6 \\
\hline Commercial farmland & 67 & 0.1 & 66 & 0.1 & -1 & -1.5 & -150 \\
\hline Forest plantation & 1,707 & 3.2 & 549 & 1.0 & -1158 & -67.8 & -5.9 \\
\hline Grassland & 12,929 & 24.3 & 15,236 & 28.7 & 2307 & 17.8 & -0.8 \\
\hline Subsistence farmland & 6,749 & 12.7 & 10,914 & 20.5 & 4165 & 61.7 & 1.5 \\
\hline Wetland & 983 & 1.8 & 613 & 1.2 & -370 & -37.6 & -10.2 \\
\hline Woodland & 24,288 & 45.7 & 22,698 & 42.7 & -1590 & -6.5 & -0.4
\end{tabular}

\section{Source: Landsat Images for 1987 and 2005}

Land cover and land use change analysis for the two study periods 1987 to 2005 showed that Kakooge rangeland ecosystems were subjected to considerable transformations (Table 2 and Figure 2). The study identified eight major land cover and land use classes, which included woodlands, built area, bush lands, forest plantations, subsistence farmlands, commercial farmlands, wetlands and grasslands as seen in Table 1. Results indicated that in the last eighteen years similar changes in land cover and land use were seen for all the land cover types except that of commercial farmlands (Table 2 and Figure 2).

Woodlands partly reduced by $6.5 \%$ for the years under analysis from 24,288 ha in 1987 to 22,698 ha in 2005 (Table 2). Overlay analysis showed that $88 \%$ of woodland was converted into other land cover types particularly built up areas, grasslands by $0.6 \%$ and subsistence farmland by $1.3 \%$ between 1987 and 2005 . However, during the same period when woodland declined, other land uses also declined. For instance, bush lands declined by $2.4 \%$ whereas wetlands reduced by $1.4 \%$ between 1987 and 2005. This showed a greater diversity in their abundance of 2.0130 diversity indices (Mbaziira, 2016). This decline in woody vegetation was attributed to increased demand for charcoal production, firewood, construction poles and expansion of farmlands. This is also evident in most East African countries where areas under forest cover were converted into grazing land, farmland or used for charcoal production (Witkowski and Garner, 2008; Mbaziira, 2016). Similar trends have been observed in rangelands of Kakooge as valuable woody species are lost daily (Zziwa et al., 2012) and we are losing the most important woody species from time to time (Abate and Angassa, 2016).

Results also indicate that the built-up area significantly increased by $822.2 \%$ with an average annual increment of 8.2 ha per year (1987 to 2005). This resulted into a decrease in woodlands from 24,288ha in 1987 to 22,698 ha in 2005 ; wetlands reduced 
to 835.4 ha (2005) at a rate of $15 \%$, forest plantations by $9 \%$ between 1987 (1707ha) and 2005 (1559.4ha) while bush lands decreased by $2 \%$ as subsistence farmlands gained more areas by $2.2 \%$, (Table 2). Dominantly the built-up areas have changed to bush lands and scrublands. Human settlements and establishments between 1987 induced this and 2005 since peace had returned into the area (Mbaziira, 2016).

Area under bush land tremendously decreased from 6,431 ha in 1987 to 2,919ha in 2005 representing 5.5\% reduction. The greatest decline in bush lands was observed between 1987 and 2005 as 3512ha; major conversions were into woodland, followed by grassland, subsistence farmland, built-up, wetland and forest plantations (Table 2 and Figure 2). This decline originated from excessive human burnings for new pastures, expansion of farmlands and over grazing (Olson et al., 2006).

Forest plantation was an alien land use form in the area that was recognised in the satellite image of 1987 . The area under pine plantations has steadily decreased from 1,707 ha in 1987 to 549 ha in 2005 , which represents a reduction of $67.8 \%$ (Table 2 and Figure 2). The analysis indicated that forest plantations had been established in areas formally under bush land, grasslands, farmlands and woodlands, but with the establishment of major settlements, this led to a $9 \%$ loss of forest plantation because of harvesting for poles and invasions by termites (Zziwa et al., 2012).

Grassland cover significantly increased by 2307ha from 12,929a in 1987 to 15,236 ha in 2005 (Table 2). There was an increase of $17.8 \%$ in grasslands during the period of analysis. These changes ought to have resulted from the conversion of woodlands, where grasslands gained by cultivation, bush and woody encroachment are the major land cover types taking over grasslands in the area (Mbaziira, 2016; Zziwa et al, 2012).

However, the conversion of grasslands into bush and woodland is rather an ecological process that involves the interplay of several factors that include management, climatic and atmospheric composition with complex feedback mechanisms involved. Overstocking and grazing, limited or complete elimination of fire as a rangeland management tool, increasing termite activity, frequent and prolonged droughts, high ambient temperatures and elevated levels of atmospheric carbon dioxide concentration are notable factors that lead to encroachment of grasslands by woodlands (Kisamba-Mugerwa, 2001).

Subsistence farmlands substantially increased throughout the year from 6,749 hectares to 10,914 hectares between 1987 and 2005 making the generate rate of increase of 4165 hectares (Table 2 and Figure 2). Overlay analysis showed that subsistence farmlands encroached on all cover types but with severe infringement on woodlands, bush lands and grasslands. According to Lambin et al. (2003), expansion of agricultural land is associated with increasing number of immigrants; during the past 18 years, there were areas of high farmland expansion in Nakasongola due to settled communities.

Commercial farmlands are yet another interesting land cover that the area has adopted. By 1987, they were occupying 67 hectares; however, by 2005, it had 
decreased to 66 hectares (Table 2 and Figure 2). This decrease was attributed to increased demand for cropland and invasion of tick making the area to longer support large herds leading to the annual rate of decline as $1.5 \%$. As earlier noted, with human population increase and changes in climate, ranching land is largely at risk (KisambaMugerwa, 2001).

Wetland cover form the dominant cover in the area covering over $80 \%$ of the total land area, though this was subjected to 370 hectares (37.6\%) decline between 1987 and 2005, having been converted into built-up and farmland areas. These changes were a result of increase in built-up and cropland areas, however, according to Mbaziira, (2016); the greatest changes in wetlands were their conversion to croplands.

\section{Drivers of land cover and land use change on the rangelands ecosystem}

Table 3: Summary of the drivers of land cover and use change

\begin{tabular}{lll}
\hline Drivers & Frequency $\mathbf{N = 2 3 8}$ & Percentage (\%) \\
\hline Socio-economic & 98 & 41.2 \\
\hline Demographic & 65 & 27.3 \\
\hline Ecological & 55 & 23.1 \\
\hline Policy & 20 & 8.4 \\
\hline Total & $\mathbf{2 3 8}$ & $\mathbf{1 0 0}$
\end{tabular}

Source: Field data, 2017

Most respondents (41.2\%) ranked socio-economic drivers as the major cause of the ever land cover and land use within the region. The prevalence of poverty forces people to turn to the natural environment as a source of livelihood, particularly, the production of charcoal as a source of fuel (Kisamba-Mugerwa, 2001; Zziwa et al., 2012). It is a known fact that the high dependency on firewood and charcoal for cooking is one of the major causes of deforestation (Ezzati et al., 2001).

The variations in the land cover and land use are related to demographic drivers (27.3\%) as reported by local inhabitants; such results are in tandem with findings elsewhere (UBOS, 2014; Mbaziira, 2016). Census data indicate that the population in Kakooge County increased from 20,622 in 2002 to 26,316 in 2014, implying that demographic expansion and consequent agricultural expansion are crucial towards land use and land cover change in any region. The study also identified ecological drivers $(23.1 \%)$ in form of unreliable rainfall and drought. This is largely supported by Zziwa et al. (2011) that unreliable rainfall and temperature extremes contribute to woody encroachment. Furthermore, notable changes in Nakasongola woodlands between 1961 and 2010 were attributed to drought (Kigenyi, Gondo and Mugabe, 2002). 
Management policies (8.4\%), namely promotion of pine growing, ranching and land tenure system were identified as part of the contributers to land cover and land use changes. Division of ranches into small farms and individualisation of the land in 1994 in Nakasongola led to increased fencing and further subdivision of land into smaller patches, that could no longer support livestock grazing hence the adoption of crop production (Zziwa et al., 2011). The ranching system restricts mobility of animals, which in turn leads to overstocking, thus limiting the regeneration of pastures/ bushes (Kisamba-Mugerwa, 2001).

\section{Impacts of land cover and land use changes on rangelands ecosystems}

\begin{tabular}{lll}
\multicolumn{3}{c}{ Table 4: Impacts of land cover and land use changes on the rangelands ecosystem } \\
\hline Effect & Frequency & Percentages (\%) \\
\hline Frequent drought conditions & 47 & 27 \\
\hline Reduced soil productivity & 32 & 18 \\
\hline Food insecurity & 29 & 17 \\
\hline Wood fuel crisis & 28 & 16 \\
\hline Biodiversity depletion & 20 & 12 \\
\hline Poor water quality and scarcity & 12 & 7 \\
\hline Atmospheric pollution & 6 & 3 \\
\hline Total & $\mathbf{1 7 4}$ & $\mathbf{1 0 0}$
\end{tabular}

\section{Source: Field data, 2017}

Following discussions with the local people, a number of impacts of land cover and land use changes on the rangelands were indentified: frequent drought (27\%), reduced soil productivity (18\%), food insecurity (17\%), wood fuel crisis (16\%), and biodiversity loss (12\%) among others. These findings are related to a study conducted in Nakasongola rangelands by Zziwa et al. (2011) who noted that socio-economic anthropogenic and ecological activities are the major factors causing degradation of rangelands.

According to the results obtained from this study's key informant interviews, woodlands, grasslands and wetlands were found to have declined by 1,590 hectares, 2,307 hectares and 370 hectares, respectively. The effects of such a decline are well illustrated by authors such as the Intergovernmental Panel on Climate Change (IPCC), (2007) and McCarthy (2002). These have demonstrated that land cover and use change contribute to regional and global changes in atmospheric composition, hence affecting the quality and quantity of primary production of livestock production; however, they also influence atrophic interactions that may accelerate further land use changes. Changes in the rangelands cover lead to rains, which are erratic, highly seasonal, and torrential in nature resulting into flooding (Zziwa et al., 2011). However, prior to the current trends in land use cover changes in most parts of the rangelands region, these regions used to significantly receive more rain $(750 \mathrm{~mm})$ which allowed crop cultivation, (Kisamba-Mugerwa, 2001); the large-scale deforestation lead to reduced rainfall and increasing temperatures, (NEMA, 2009). 
In most parts of the study area, the effects of drought tend to be very severe and are reflected in the less cloud cover, while accumulation of smoke from bush fires contributes to the build-up of atmospheric carbon dioxide and that contributes to global climate change (NDC, 2007; NEMA, 2009). Generally, global temperatures' average surface warming was to rise between $1.8^{\circ} \mathrm{C}$ and $4.0^{\circ} \mathrm{C}$, by 2010 which was approximated to cause $20-30 \%$ of plant and animal species to be at risk of extinction in the rangelands (Food and Agricultural Organisation (FAO), 2007).

The subsequent conversion of land cover patterns severely alters ecosystem functionality and shifts them to a different stable state as noted by Lambin et al. (2001), that biodiversity functionality is always low given increasing population pressure. Consequently, the livelihood of communities that depend on the integrity of natural ecosystems for products and services becomes increasingly threatened (IPCC, 2007). This can further be exemplified by a biomass study per district in Uganda, which revealed that the rate of timber/deforestation between 1990 and 2005 reduced total forest cover by $60 \%$ in Nakasongola District Council ((NDC), 2009). According to National Land use policy (2006), land use cover affected by over-grazing leads to bush encroachment and emergence of other obnoxious plants that in turn reduces the available pasture.

In most parts of the cattle corridor, the effects of drought tend to be very severe resulting into a rise in loss of animal, water scarcity and food shortages. This concurs with Kisamba-Mugerwa (2001) and FAO (2007) reports that temperature varies greatly in the cattle corridor depending on the rainfall seasons and the amount of cloud cover on the skies. Moreover, accumulation of smoke from bush fires contributes to the build-up of atmospheric carbon dioxide, which in turn contributes to global climate change (NDC, 2009; NEMA, 2009).

Continued conversion of forestland into agricultural land has induced deforestation (McCarthy, 2002) and soil degradation (Ezzati et al., 2001) in Nakasongola District, while the continued pastoral activities like seasonal bush burning expose land to other vagaries like water and wind erosion (NDC, 2009 and Muleneh, 2003).

\section{Conclusion of key results}

This research exhibits spatial and temporal dynamics in land cover and land use ecosystems observed at high scales from 1987 to 2005. Major expansions were witnessed among built-up areas by $822.2 \%$, followed by subsistence farmlands $61.7 \%$ and grasslands $17.8 \%$, and a fast shrinkage in forest plantation $67.5 \%$, wetland $37.6 \%$, woodland $6.5 \%$ and commercial farmland $1.5 \%$.

Charcoal production, population pressure, poverty, drought and introduction of pine trees are major driving forces, which have had immense impacts on the rangelands' ecosystem resulting into frequent droughts, reduced soil productivity, food insecurity, and wood fuel crisis, destruction of crops by wind and poor water quality and scarcity. These call for immediate actions to secure the land cover within 
the region by conducting scientific experimental investigations. These would establish the degradation threshold beyond which land uses like charcoal making and grazing become destructive to rangeland ecosystems. They would also encourage government to undertake land use monitoring as well as formulation of clear policies for communities to adopt to mitigate the losses originating from land use and land cover changes.

\section{References}

Abate, T., and Angassa, A., 2016. Conversion of savanna rangelands to bush dominated landscape in Borana, Southern Ethiopia. Ecological processes, 5(1): p.6

Agarwal, C., Green, G. M., Grove, J. M., Evans, T. P., and Schweik, C. M., 2002. A review and assessment of land-use change models: Dynamics of space, time, and human choice. General Technical Report NE-297. Newtown Square, Pennsylvania: U.S. Department of Agriculture, Forest Service, Northeastern Research Station. [Online] Available From: http://nrs.fs.fed.us/pubs/gtr/gtr_ne297.pdf [Accessed 25 September 2015]

Amanuel, A., and Mulugeta, L., 2014. Detecting and quantifying land use/land cover dynamics in Nadda Asendabo watershed, South Western Ethiopia. International. Journal for Environment Science. Vol.3(1):45-50

Beza, T. A., 2011. Land cover dynamics in Savanna Ecosystem of Borena Ethiopia. Doctoral dissertation

Congalton, R. G., and Green, K., 2008. Assessing the accuracy of remotely sensed data: principles and practices. [Online] Available From: https://books.google.com/books?hl=en\&lr= \&id=T4zj2bnGldEC\&oi=fnd\&pg=PP1\&ots=RSlAgrp4_x\&sig=sVdxs0iNCRcVHzpde6ocrif5-g [Accessed 21 June 2017]

Egeru, A., Wasonga, O., Kyagulanyi, J., Majaliwa, G. M., MacOpiyo, L., and Mburu, J., 2014. Spatio-temporal dynamics of forage and land cover changes in Karamoja sub-region, Uganda. Pastoralism, Vol. 4(1): p.6

Ezzati, M., Singer, B. H., and Kammen, D. M., 2001. Towards an integrated framework for development and environment policy: the dynamics of environmental Kuznets curves. World Development, Vol. 29(8): 1421-1434

IPCC, 2007. Climate Change 2007: Impacts, Adaptation and Vulnerability. Report of the working Group II. Cambridge University Press, UK. [Online] Available From: https://www.ipcc.ch/pdf/assessment-report/ar4/wg2/ar4_wg2_full_report.pdf [Accessed 14 March 2018]

FAO, 2007. Trees outside forests, towards better awareness. Conservation guide 35.9 - 35, FAO, Rome \& ACCARD

GLCF., 2014. Global Land Cover Maps; global LC maps for the 1986, and 2005 epochs. [Online] Available From: http://maps.elie.ucl.ac.be/CCI/viewer [Accessed 01 October 2014] 
Kafeero, F., 2007. The impact of water shortage on forest resources-the case of Uganda, Environment alert, Kampala Uganda. vol. 58

Kigenyi, F., Gondo, P., Mugabe, J., 2002. Analysis of policies and institutional change, enabling community involvement in forest management in Eastern and Southern Africa. IUCN - EARO, Nairobi

Kimiti, K. S., Wasonga, O. V., Western, D., and Mbau, J. S., 2016. Community perceptions on spatio-temporal land use changes in the Amboseli ecosystem, southern Kenya. Pastoralism, Vol. 6(1): 24

Kisamba-Mugerwa, 2001. Rangeland policy management in Uganda, HammanetTunisia

Lambin, E. F., Turner, B. L., Geist, H. J., Agbola, S. B., Angelsen, A., Bruce, J. W., $\mathrm{Xu}, \mathrm{J} ., 2001$. What drives deforestation? A meta-analysis and underlying causes of deforestation based on Sub-national case study evidence. Louvaine-la-Neuve, Belgium: LUCC International Project Office, LUCC Report Series no. 4.

Lambin, E. F., Geist, H. J., and lepers, E., 2003 Dynamics of land-use and land cover change in tropical regions. Annual review of environmental resources, 28:205-41

Mbaziira, J., 2016. Effects of land use cover changes on rangeland ecosystems in Uganda Lambert Academic Publishers- Germany, Pg. 20-45

McCarthy, N., 2002. The effects of environmental variability on livestock and land use management; the Borana Southern Ethiopia. Socio-economics and policy research working paper 35, International Livestock Research Institute, Nairobi, Kenya

Ministry of water, lands and environment, 2003. National biomass study technical report. Kampala

Muleneh, W. T., 2003. Impact of population pressure and land use and land cover changes, agricultural system and income diversification in West Guraque, Ethiopia. PhD, dissertation, submitted to Norwegian University of Science and Technology, Trondheim

Mwavu, E. N, and Witkowski, E. T. F., 2008. Land-use and cover changes (19882002) around Budongo forest reserve, North West Uganda: Implications for forest and woodland sustainability. Land Degradation and Development 19: pp. 606-622

Nakasongola District Council, 2009. District state of environment report. 2: pp.15-18

NEMA, 2008. State of the Environment report ministry of natural resources, Kampala vol. 2. Pg 4-7

NEMA, 2009. The National Environmental Management newsletter on climate changes, Kampala, No. 3: pp. 2 -3

Olson, .J. M, Misan, .S., Campbell, .D. J, Mbonile, .M., Mugisha,. S., 2004. Land use change impact and dynamics project. Working Paper, International Livestock Research Institute, Nairobi

Sreenivasulu, G., Jayaraju, N., Kishore, K. and Lakshmi, P. T., 2014. Land use and land cover analysis using remote sensing and GIS: A case Study in and around Rajampet, Kadapa District, Andhra Pradesh, India. Indian Journal of Science Research, Vol. 8(1): 123-129 
Tsegaye, D. M., Tsunekawa, A., Tsubo, M., Haregeweyn, .N., 2012. Dynamics and hotspots of soil erosion and management scenarios of the Central Rift Valley of Ethiopia. International Journal of Sediment Research, 27: 84-99

UBOS, 2014. Uganda population and household census report 2014. [Online] Available From: http://www.ubos.org [Accessed 14 February 2018]

National Land Use Policy, 2006. [On line] Available From: http://mlhud.go.ug/wpcontent/uploads/2013/08/National-Land-use-Policy.pdf [Accessed 03 September 2018]

Witkowski, E. T. F., and Garner, R. D., 2008. Seed production, seed bank dynamics, resprouting and long term response to clearing of the alien invasive Solanum mauritianum in a temperate to sub-tropical riparian ecosystem. South African Journal of Botany, 74: 476-484

Zziwa, E., Kironchi, G., Gachene, C., Mugerwa, S. and Mpairwe, D., 2012. Production systems, land cover change and soil factors affecting pasture production in semi-arid Nakasongola. International Journal of Agronomy and Agricultural Research, Vol. 2(7): 6-17.

Zziwa, E., Kironchi, G., Gachene, C., Mugerwa, S., and Mpairwe, D., 2012. The dynamics of land use and land cover change in Nakasongola district. Journal of Biodiversity and Environmental Sciences, Vol. 2(5):61-73

\section{Author Biography}

James Mbaziira's career interests are spatial planning, landscape ecology, climate change, disaster risk reduction and rural sustainability with links to livelihood and community resilience and land use cover change analysis. He is a member of the International Geography Union, serves as the coordinator and teacher of geography for the Uganda Geographical Association and is currently a $\mathrm{PhD}$ Geography student at Makerere University. He is also the Head of Department and Lecturer of Geography in the Faculty of Education at Uganda Martyrs University. 